\title{
Zaimul Asroor \\ ISLAM TRANSNASIONAL VS ISLAM MODERAT: Upaya NU dan MD dalam Menyuarakan Islam Moderat di Panggung Dunia
}

UIN Syarif Hidayatullah, Jakarta

Email: asroraim7@gmail.com

Received:

2019-12-01

Received in revised form:

2019-12-16

Accepted:

2019-12-21

\section{Citation:}

Asroor, Z. (2019),

Islam Transnasional vs

Islam Moderat: Upaya

NU dan MD dalam

Menyuarakan Islam

Moderat di Panggung

Dunia, 6(2), 171-213.

\begin{abstract}
Transnational ideologies with a "fierce" face such as HTI, Muslim Brotherhood and Salafi have progressed from year to year, especially after the reformation. This is evidenced by their success infiltrated into the bodies of two large Indonesian Islamic organizations known to be very moderate (NU and MD) in the 2006-2007s. In response to this, the 33rd NU conference and the 47th MD conference in 2015 seemed to be evidence of the seriousness of the two organizations to not only improve themselves after being infiltrated but also to make both of them intensified to introduce Indonesian Islamic patterns to the outside. This paper concludes that the face of moderate Islam in Indonesia will be maintained as long as NU and MD remain steadfast as the "bodyguards" of the Republic of Indonesia. More than that, both of them are determined to utter a new Islamic model typical of Indonesia on the world stage, namely Islam Nusantara Berkemajuan. Therefore, the efforts of the transnational movement whose agenda is to replace the foundation of the Indonesian state into a caliphate will end in vain.
\end{abstract}

Keywords: Moderate Islam, Indonesia's Contributions, NU, $M D$, Transnational Ideology.

${ }^{1}$ Sebagian dari materi tulisan ini pernah penulis presentasikan dalam International Conference yang diadakan UIN Walisongo Semarang, dengan tema "The Contribution of Indonesian Islam to the World: Past, Present and Future", 13, November 2019.Adapun penulis sekarang tinggal di Jl. Kertamukti, Gg Telaga Hijau, NO 69, Ciputat Timur, Tangerang Selatan, Banten.

At-Turäs: Jurnal Studi Keislaman

E-ISSN: 2460-1063, P-ISSN: 2355-567X

Volume 6, No. 2, Juli-Desember 2019 


\begin{abstract}
Abstrak: Ideologi transnasional yang berwajah "sangar" seperti HTI, Ikhwanul Muslimin dan Salafi mengalami kemajuan dari tabun ke tahun, kbususnya pasca reformasi. Hal ini dibuktikan dengan keberbasilan mereka menyusup ke dalam tubuh dua ormas besar Islam Indonesia yang dikenal sangat moderat(NU dan MD) pada tabun 2006-2007an. Menyikapi hal ini, muktamar NU ke-33 dan muktamar MD ke-47 pada tabun 2015 tampaknya menjadi bukti keseriusan kedua ormas ini untuk tidak hanya berbenah diri setelah disusupi, akan tetapi juga membuat keduanya semakin gencar untuk memperkenalkan corak keislaman Indonesia ke luar. Tulisan ini menyimpulkan bahwa wajah Islam moderat di Indonesia akan tetap terjaga selama NU dan MD tetap teguh menjadi "pengawal" NKRI. Lebih dari itu, keduanya bertekad untuk menyuarakan model keislaman baru khas Indonesia di panggung dunia, yakni Islam Nusantara Berkemajuan. Oleh karena itu, upaya gerakan transnasional yang salah satu agendanya ingin mengganti dasar negara Indonesia menjadi khilafah akan berakhir sia-sia.
\end{abstract}

Kata kunci: Islam Moderat, Kontribusi Indonesia, NU, MD, Ideologi Transnasional.

\title{
PENDAHULUAN
}

Diakui atau tidak, gerakan politik transnasional telah menghasilkan konflik internal antar agama dan separatisme di Indonesia. Ideologi transnasional juga layaknya pedang yang siap merobek rajutan kesepakatan bersama yang dibangun oleh founding fathers kita puluhan tahun silam. ${ }^{2}$ Ideologi transnasional bisa dimaknai sebagai ideologi global yang melintasi batas negara dan bangsa. Ia juga bukan hanya sebuah kampanye propaganda atau kepercayaan. Lebih dari itu, ia dapat mempengaruhi kebijakan politik dalam sebuah negara. Cita-cita kelompok Islam transnasional untuk memberlakukan syariat Islam bahkan mengganti Pancasila tentu tidak seiring dengan AD/ART dua ormas besar Islam di Indonesia, Nahdlatul Ulama' dan Muhammadiyah. Dua ormas yang terkenal moderat ini menjadi garda terdepan dalam menghalau infiltrasi ideologi transnasional yang dianggap tidak cocok

${ }^{2}$ http:/ / www.neraca.co.id/article/83863/transnational-ideology-vs-pancasila-ideology-in-lifeof-nation-and-state. Diakses pada 24-10-2019. 
dengan kultur keislaman Indonesia yang santun, toleran dan tidak mudah mengkafirkan.

Namun demikian, dalam beberapa tahun terakhir peneliti seperti Martin Van Bruinessen melihat adanya perubahan warna keislaman Indonesia yang condong ke arah konservatif. Dalam bukunya Contemporary Development in Indonesian Islam, Explaining the "Conservative Turn", ia menunjukkan bahwa kecenderungan konservatisme tidak saja muncul dalam gerakan-gerakan Islam kontemporer yang lahir pasca reformasi, tetapi juga merasuk ke dalam tubuh ormas Islam yang sudah mapan, seperti MUI dan Muhammadiyah. ${ }^{3}$ Hal ini tentu kabar yang tidak menggembirakan, terlebih misalnya bagi Muhammadiyah (MD) yang dikenal sebagai "kawan" lama Nahdlatul Ulama (NU) dalam mendengungkan Islam berwajah moderat.

Dilandasi oleh latar belakang di atas, penulis melihat terdapat adanya "pertarungan" wacana yang besar antara pemerintah Indonesia di satu sisi-yang dalam hal ini terwakili oleh NU dan MD sebagai penjaga gawang Islam moderat—dan penyokong Islam transnasional di sisi lain. Hasil dari pertarungan ini akan menentukan wajah Islam ke depan, karena itu pula tulisan ini disajikan.

\section{METODE PENELITIAN}

Penelitian ini merupakan penelitian pustaka. Karena itu dalam penelitian ini penulis lebih menitik beratkan padai buku, jurnal, web, dan lain-lain sebagai sumber utama kajiannya. Adapun terkait sumber primer yang penulis gunakan tidak terpaku pada satu buku saja, akan tetapi dari

\footnotetext{
3 Din Wahid, 'Kembalinya Konservatisme Islam Indonesia', Studia Islamika, 21.2 (2014) <https://doi.org/10.15408/sdi.v21i2.1043>. 
beberapa buku yang penulis anggap penting dan sering dijadikan rujukan. Seperti misalnya Ilusi Negara Islam: Ekspansi Gerakan Transnasional di Indonesia, Arus Baru Islam Radikal: Transmisi Revivalisme Islam Timur Tengah ke Indonesia, Hasil-hasil Muktamar NU ke-33 tahun 2015 dan Tanfidz Keputusan Muktamar Muhammadiyah ke-47 tabun 2015. Adapun sumber sekunder yang penulis gunakan berupa artikel, buku, web NU Online, Muhammadiyah.or.id dan beberapa web lain yang bisa mendukung data penelitian.

Penulis juga menggunakan metode komparasi untuk membandingkan antara NU dan MD, ditinjau dari pertama kali organisasi ini didirikan, era reformasi sampai era sekarang. Perbandingan ini penting untuk melihat sejauh mana kedua ormas ini berkiprah dalam menyuarakan gagasan Islam moderat dan membendung gelombang Islam transnasional di Indonesia. Untuk melihat aspek continuity and change dari kedua ormas ini, begitu juga warna keislaman Indonesia, penulis menggunakan pendekatan historis. ${ }^{4}$

\section{PEMBAHASAN}

\section{ISLAM MODERAT VS ISLAM TRANSNASIONAL: SEBUAH PEMAHAMAN AWAL}

Dalam KBBI, kata moderat memiliki dua makna: pertama, selalu menghindarkan perilaku atau pengungkapan yg ekstrem; kedua, berkecenderungan ke arah dimensi atau jalan tengah. ${ }^{5}$ Muchlis Hanafi memaknai moderat (al-wasath) sebagai metode berpikir, berinteraksi dan berperilaku secara tawazun (seimbang) dalam menyikapi dua keadaan, sehingga ditemukan sikap yang sesuai dengan prinsip-prinsip Islam dan

\footnotetext{
${ }^{4}$ Taufik Abdullah, Sejarah Dan Masyarakat (Jakarta: Pustaka Firdaus, 1987). Hal. 105.

5 Dendy Sugono (Pemimpin red), Kamus Besar Bahasa Indonesia (Jakarta: Pusat Bahasa Departemen Pendidikan Nasional, 2008). Hal. 1035.
} 
tradisi masyarakat, yaitu seimbang dalam akidah, ibadah dan akhlak. Dilihat dari sumber utama ajaran Islam, moderat-menurut Khaled M. Abou Fadl-dapat ditemukan lewat al-Qur'an yang selalu memerintahkan umat Islam untuk menjadi orang yang moderat, dan alSunnah yang menggambarkan sosok Nabi yang menunjukkan tipikal orang moderat, tatkala dihadapkan pada dua pilihan ekstrem, maka Nabi selalu memilih jalan tengah. ${ }^{6}$

Bila melihat penjabaran Khaled di atas, secara preseden, Islam memiliki legitimasi yang sangat kuat dalam menyuarakan gagasan moderasi dalam beragama. Maksudnya, secara teoritis ajaran moderat bisa ditemukan dalam beberapa ayat-ayat al-Qur'an. Misalnya surat alBaqarah: 143 "Wa kadzalika ja'alnakum ummatan wasata”, yakni sebagai umat pertengahan. Bahkan dengan jelas al-Tabari menakwili kata wasata dengan arti al-'Adl (adil). Menurutnya, ini karena manusia yang dipilih adalah mereka yang adil atau Muqsit (terulang tiga kali dalam al-Qur'an). ${ }^{7}$ Adapun secara praktis, Nabi Muhammad menjadi panutan nyata yang membawa ajaran Islam yang moderat, tidak berlebih apalagi kurang. Hal inilah yang membuat Islam dapat diterima bangsa Arab waktu itu.

Islam moderat juga bisa diklasifikasi sebagai individu dan organisasi. Secara individu, seorang disebut moderat ketika menerima dan menghargai pandangan dan keyakinan yang berbeda sebagai fitrah, tidak memaksakan kebenaran yang diyakininya kepada orang lain (baik secara langsung atau melalui pemerintah). Dalam konteks Indonesia,

${ }^{6}$ Khaled M. Abou El-Fadl, Selamatkan Islam dari Muslim Puritan, terj. Helmi Mustofa (Jakarta: Serambi Ilmu Semesta, 2006). Hal. 17.

7 Abu Ja'far Muhammad Al-Thabari, 'Jami' Al-Bayan Fi Tafsir Al-Qur'an' (Dar al-Hijr). Juz 2, Hal. 627. Menurut Ridha, kenapa Islam dikatakan sebagai umat tengah? Ini karena umat sebelumnya apabila bersikap bisa dibagi menjadi dua; berlebihan sampai meninggalkan urusan agama, atau berlebihan dalam beragama sampai meninggalkan urusan dunia. lihat Muhammad Rasyid Ridha, Tafsir al-Manar (Mesir: Hai'ah Misriyyah, 1990) juz 2, 5. 
menerima dasar negara Pancasila sebagai landasan hidup bersama dan bentuk NKRI sebagai konsensus final dalam berbangsa dan bernegara yang melindungi keberagaman yang ada di tanah air. Sedangkan secara organisasi, organisasi bisa dikatakan moderat ketika sesuai dengan karakter individu moderat, ditambah dengan visi dan misi yang menerima dasar negara Pancasila sebagai landasan hidup bersama berbangsa Indonesia dan bentuk NKRI sebagai sebuah konsensus final dalam kehidupan berbangsa dan bernegara. ${ }^{8}$

Jika demikian, dapat disimpulkan bahwa apabila ada sekelompok golongan yang mengatasnamakan Islam akan tetapi perilaku keberagamaannya berlebihan—entah ke arah "kanan" atau "kiri"berarti mereka bisa dikatakan keluar dari rel Islam moderat, implikasinya adalah kurang patut untuk dijadikan panutan. Lalu, apa hubungannya Islam moderat dengan Islam transnasional? Apakah keduanya bertentangan dan selalu bersinggungan? Berikut gambaran singkat tentang Islam Transnasional.

Istilah transnasional merupakan gabungan dari dua kata; "trans" yang berarti melintang, melintas, menembus dan melalui. Kemudian "nasional" yang berarti bersifat kebangsaan, berkenaan atau berasal dari bangsa sendiri.' Dalam kamus Oxford, keduanya diartikan sebagai berikut, trans yang berarti "something that is present or moves from one place to another (on or from the other side of)". Sedangkan national diartikan "a nation or a group of societies which as a whole form the citizens of a state". ${ }^{10}$ Istilah transnasional awalnya merupakan sebuah aktifitas diaspora, di mana aktifitas itu ditunjukkan dengan berpindahnya suatu penduduk ke negara lain. Pada perkembangan selanjutnya, istilah

8 Abdurrahman Wahid (ed), Ilusi Negara Islam: Ekspansi Gerakan Transnasional di Indonesia (Jakarta: The Wahid Institute, 2009). Hal. 46-47.

${ }^{9}$ Sugono, Kamus, 1728 dan 1068.

10 The Oxford Paper Back Dictionary (London: Oxford University Press, 1994). Hal. 357. 
transnasional mulai bergeser menjadi suatu interaksi antara seseorang atau institusi yang melewati batas negara nasional modern. ${ }^{11}$

Dalam kaitannya dengan agama, khususnya Islam, gerakan Islam transnasional (transnational Islamic movement) dapat diterjemahkan dengan suatu gerakan yang memiliki ajaran atau ideologi yang datang dari satu negara ke negara lain. Ia tidak muncul dari dalam, sebaliknya muncul dari luar untuk mempengaruhi warna Islam yang sudah ada dalam sebuah negara. Hal ini sesuai dengan penjelasan Peter Mandaville yang mengatakan bahwa gerakan Islam transnasional dapat dimaknai sebagai gerakan yang tidak hanya terbatas pada wilayah lokal atau nasional. Sebaliknya, aktifitas dan organisasinya jauh melampaui sekat teritorial wilayah (negara bangsa). ${ }^{12}$

Kalau boleh disederhanakan, gerakan Islam transnasional dapat dicirikan sebagai gerakan yang memperjuangkan beberapa hal berikut: ajaran Islam yang utuh (kaffah), Islam yang tidak memisahkan agama dan negara, penerapan syariat di seluruh aspek kehidupan, menjadikan umat Islam menjadi satu (ummah) melalui khilafah, romantisme terhadap model kekhalifahan Islam sebagaimana di masa Nabi dan sahabat. ${ }^{13}$

Sebagai misal, Hizbut Tahrir Indonesia (HTI). Pelabelan Islam transnasional terhadap kelompok ini tidak bisa terpisahkan dari agenda yang mereka perjuangkan, yakni proses transfer ideologi tanpa melalui proses akulturasi. Proses ini (transfer ideologi) terjadi tanpa memperhatikan konteks budaya lokal dalam sebuah masyarakat. Di samping itu, masyarakat juga "dipaksa" untuk menerima ideologi mereka secara menyeluruh tanpa diberi kesempatan untuk mempertanyakan 1, (2010).

${ }^{11}$ Ihzan Yilmaz, 'Transnational Islam', European Journal of Economic and Political Studies,

12 Peter Mandaville, Global Political Islam (London:Routledge, 2007). Hal. 279.

${ }^{13}$ Yilmaz, ‘Transnational Islam', hal. 2. 
validitas ajaran dan ideologi mereka. ${ }^{14}$ Ketika masyarakat sudah terpengaruh ajaran Islam transnasional, maka diharapkan keislaman mereka tidak akan terkontaminasi lagi dengan budaya lokal. Ini karena Islam lokal dianggap telah menyimpang dari ajaran Islam yang murni.

Perlu diingat, dalam konteks Indonesia, HTI adalah satu dari sekian ideologi transnasional yang pernah menjamur. Bahkan bisa dikatakan HTI memiliki pengikut cukup besar. Selain HTI, masih ada gerakan transnasional lain yang masih "berkeliaran” bebas di tanah air. Seperti misalnya Salafi (Wahabi), Syiah dan Ikhwanul Muslimin (IM), Jemaah Islamiyah, bahkan ISIS. ${ }^{15}$

Itulah gambaran sekilas tentang Islam moderat dan Islam transnasional. Sebelum membahas secara spesifik keduanya, penulis merasa perlu mengurai benang merah sejarah awal Islam Indonesia sehingga jelas bagaimana sebenarnya Islam Indonesia bermetamorfosa dari waktu ke waktu.

Bila melacak akar sejarah pertama kali agama-agama di Nusantara_terlepas dari perbedaan teori yang muncul ${ }^{16}$ _beberapa peneliti termasuk di antaranya Azyumardi Azra menyimpulkan bahwa Islam adalah agama belakangan yang baru masuk ke negeri ini sekitar abad ke 7 M. Sebelumnya, masyarakat Indonesia_-atau kala itu disebut Nusantara-lebih dulu menganut agama seperti Hindu dan Budha, ${ }^{17}$ begitu juga kepercayaan-kepercayaan lain seperti Animisme dan

14 Thomas NA, dkk, 'Pancasila Ideology vs Transnational Ideology Movement' Proceeding, The 5th International Conference on Education \& Social Sciences (ICESS), hal. 568.

15 Zainul Mu'ien Husni, 'Nu Di Tengah Pusaran Ideologi-Ideologi Transnasional', Jurnal Islam Nusantara, 2.1 (2018), 45 <https://doi.org/10.33852/jurnalin.v2i1.68>. Lihat juga Jamhari (peny), Gerakan Salafi Radikal di Indonesia (Jakarta: Raja Grafindo, 2004), x. Lihat juga Eko Kurniawan Wibowo, 'Membincang Gerakan Islam Transnasional' Diegesis: Jurnal Teologi, 3.3 (2018), 62

${ }^{16}$ Ahmad Mansur Suryanegara, Api Sejarah 1 (Bandung: Surya Dinasti, 2015). Hal. 99-100.

${ }_{17}$ Awal pengaruh Hindu Budha di Nusantara dimulai dari abad ke-5 M. yang ditandai dengan kehadiran kerajaan Kutai dan Tarumanegara di bumi Nusantara. Lihat Agustijanto Indradjaja, 'Awal Pengaruh Hindu Budha di Nusantara', Kalpataru, Majalah Arkeologi, 23.1, (2014), 17. 
Dinamisme. ${ }^{18}$ Bila Islam adalah agama yang datang belakangan, lalu kenapa Islam sekarang menjadi agama yang dianut oleh mayoritas masyarakat di Indonesia?

Riklefs sendiri merasa kesulitan untuk menjawab pertanyaan di atas, ini disebabkan karena kurangnya sumber tentang Islamisasi di Indonesia. Kalaupun ada, sangat langka dan sering tidak informatif. Ia berpendapat bahwa setidaknya ada dua proses Islamisasi yang mungkin telah terjadi. Pertama, penduduk pribumi mengalami kontak dengan Islam dan kemudian menganutnya. Kedua, orang-orang asing asia (Arab, India, Cina, dll) yang beragama Islam tinggal di wilayah Indonesia lalu menikah dengan penduduk asli, dan mengikuti gaya hidup lokal sedemikian rupa. ${ }^{19}$ Di sini terlihat Riklefs cukup kesulitan menganalisa bagaimana agama Islam akhirnya bisa menjadi agama mayoritas di Indonesia.

Terlepas dari sulitnya memastikan faktor yang menjadikan Islam sebagai agama yang akhirnya diterima masyarakat Indonesia, ada semacam kesepakatan sejarah yang menunjukkan bahwa Islam masuk ke Nusantara dengan cara yang "unik" dan tanpa kekerasan, ${ }^{20}$ yakni dengan pendekatan sufistik-kultural. Memang pada abad ke-7, Islam belum mendapatkan "sambutan" yang meriah dari masyarakat di Nusantara. Akan tetapi, memasuki abad ke-15-menurut beberapa peneliti seperti Jan S Aritonang dan Agus Sunyoto-Islam menemukan momentumnya

\footnotetext{
18 Terkait pembahasan Animisme dan Dinamisme bisa merujuk pada Zakiyah Drajat (peny) Perbandingan Agama I (Jakarta: Bumi Aksara, 1996). Hal. 28. Edward B. Tylor, Primitive Culture: Research into the Development of Mythology, Philosophy, Religion, Language, Art and Custom (New York: Brentano's Publishers, t.t.). Hal.160.

${ }^{19}$ Merle Calvin Ricklefs, A History of Modern Indonesia since c 1200, $3^{\text {rd }}$ edition (Great Britain: Palgrave, 2001). Hal. 3.

20 Riklefs memberi catatan, bahwa dalam beberapa hal setelah kerajaan Islam berdiri di Indonesia, kadang-kadang diiringi dengan peperangan. Seperti misalnya yang terjadi di Sumatera dan Jawab pada abad ke-16. Namun perlu dicatat bahwa ini tidak berarti bahwa peperangan semacam itu dilakukan terutama untuk menyebarkan agama Islam. Lebih dari itu, sebab-sebab peperangan lebih besar dikarenakan adanya faktor kewangsaan, strategi dan ekonomi. Memang, seringnya Islamisasi terjadi setelah penaklukan. Ibid., 17.
} 
(mulai banyak dianut masyarakat.pen). ${ }^{21}$ Jadi, Islam tidak diterima begitu saja di bumi Nusantara selama tujuh sampai delapan abad lamanya. Bisa dibayangkan betapa lamanya proses ini. Ungkapan Agus senada dengan apa yang diungkapkan A.H. Jhons begitu juga Azyumardi Azra melalui teori sufinya (sekaligus menolak teori-teori sebelumnya yang dianggapnya kurang valid). Menurutnya Islamisasi di bumi Nusantara dilakukan oleh para guru sufi. Guru sufi inilah yang membawa Islam dari satu tempat ke tempat yang lain. Contoh para guru sufi ini adalah Walisongo. Mereka menyebarkan Islam di pulau Jawa. Dalam menyebarkan agama Islam, para guru sufi ini sangat akomodatif sekali. Walisongo mempunyai landasan bahwa yang penting masyarakat masuk Islam dulu, pada saat yang sama menerima praktek-praktek yang lama, tradisional, bahkan mungkin kepercayaan lokal. Karena mereka percaya bahwa ajaran-ajaran Islam akan diterima di masa mendatang. ${ }^{22}$

Corak Islam Indonesia yang bercorak sufistik itu terus bertahan dan berkembang sampai akhirnya menggantikan "tahta" agama Hindu Budha, yang sudah dianut terlebih dahulu oleh masyarakat, pada abad ke 16. ${ }^{23}$ Selain bercorak sufistik, muslim tradisional Indonesia juga sangat berpegang teguh pada ajaran sunni. Di sinilah peran kiai melalui pesantrennya begitu kuat. Bahkan beberapa aspek Islam tradisional juga mempengaruhi budaya lokal dan adat setempat. Meski demikian, pertemuan Islam dan budaya lokal ini sering disalahpahami sebagai penyebab kurang murninya ajaran Islam Indonesia. ${ }^{24}$ Padahal ajaran tasawuf yang dikembangkan para guru sufi adalah tasawuf yang berpadu

21 Jan S. Aritonang, Sejarah Perjumpaan Kristen dan Islam di Indonesia (Jakarta, Bpk Gunung Mulia, 2004). Hal. 15. Agus Sunyoto, Atlas Walisongo (Depok: Pustaka Ilman, 2016). Hal. 55.

22 Azyumardi Azra, Islam With Smiling Face (Video Democracy Project, Yayasan Abad Demokrasi, 2013).

${ }^{23}$ Fahrida Inayati dan Adib Rifqi Setiawan, 'Islam Nusantara: Glance History, Characteristics, and Criticism', Alobatnio Research Society ( $\Lambda \mathrm{RS})$, March 24, (2018).

${ }^{24}$ Hanum Jazimah Puji Astuti, 'Islam Nusantara: Sebuah Argumentasi Beragama dalam Bingkai Kultural', INJECT: Interdisciplinary Journal of Communication, 2.1 (2017), 40. 
dengan syariah secara seimbang. Berbeda misalnya dengan kaum Batiniyah di masa al-Ghazali yang melupakan aspek syariah.

Dua hal penting perlu dijadikan catatan di sini, yakni adanya proses persinggungan yang saling menguatkan antara Islam bercorak sufistik dengan tradisi yang telah ada di masayarakat jauh sebelum Islam datang, khususnya jawa. Beberapa tradisi yang ada seperti penghormatan yang tinggi pada seorang kiai, menghormati tokoh terkemuka seperti Walisongo, tradisi ziarah kubur, tahlilan, maulid nabi, termasuk upacara sekaten, penggunaan beduk sebagai pengingat waktu shalat dan lain sebagainya dipraktekkan oleh kalangan muslim tradisional selama berabad-abad lamanya tanpa memandang bahwa tradisi ini bertentangan dengan Islam.

Akan tetapi, nuansa Islam kultural khas Indonesia di atas mulai diuji dengan datangnya paham modernis salafi yang kemudian diikuti oleh paham Wahabi dari Arab Saudi. Menurut paham ini, beberapa tradisi yang dipraktekkan masyarakat Islam Indonesia disebut sebagai bid'ah dan syirik yang dapat merusak kemurnian Islam. Kondisi inilahdalam perkembangan awalnya-membawa perselisihan antara Nahdlatul Ulama (sebagai muslim tradisional) dengan Muhammadiyah (sebagai modernis puritan). ${ }^{25}$ Muhammadiyah sebenarnya bukanlah kelompok awal pembawa ide puritanisme Islam di Indonesia. Karena sebelum organisasi ini lahir, beberapa dekade sebelumnya telah muncul kelompok puritan di pulau seberang, yakni Sumatera Barat. Seperti apa mereka?

25 Inayati, "Islam Nusantara". 


\section{PERANG PADRI: AWAL DARI GERAKAN TRANSNASIONAL (WAHABI)}

Di pembahasan sebelumnya penulis telah memberikan gambaran singkat tentang watak Islam yang dibawa oleh para Guru sufi. Mereka memperkenalkan Islam kepada masyarakat Indonesia, khususnya Jawa melalui berbagai macam media berbasis kultural sehingga mudah diterima oleh masyarakat yang saat itu masih sangat kental dengan berbagai tradisi Hindu Budha. Kelihaian para guru sufi (di antaranya yang terkenal Walisongo) memadukan ajaran Islam dengan pendekatan sufistik bahkan mistik ini akhirnya tidak membuat masyarakat merasa terancam. Agama dan budaya akhirnya berjalan beriringan selama beberapa abad tanpa ada yang merasa dirugikan.

Akan tetapi, memasuki abad ke 19, ajaran Wahabi di Arab Saudi ternyata layaknya virus yang telah menjangkit para agamawan seperti Haji Miskin, Haji Abdurrahman dan Haji Muhammad Arif. Sekembalinya dari ibadah haji-tepatnya pada tahun 1803 M-mereka melihat bahwa praktek keagamaan yang dilakukan oleh masyarakat muslim di Indonesia, khususnya di Sumatera Barat, telah menyimpang dari ajaran murni sebagaimana yang mereka dapatkan ketika di Arab. Praktek-praktek yang menyimpang itu—versi para Padri-seperti pengkramatan kuburan orang soleh, penggunaan sirih, sabung ayam, dll. Mereka juga mewajibkan masyarakat lokal solat lima waktu (bagi yang melanggar didenda), para wanita harus menutup wajah, dll. ${ }^{26}$ Karena tidak semua masyarakat menerima gagasan mereka, akhirnya perang saudara dan sesama muslim itu pun terjadi, hal ini sekaligus menjadi peristiwa kelam dalam sejarah Islam Nusantara. Namun cukup disayangkan sejarah Hal. 54.

${ }^{26}$ Solahudin, NII Sampai JI: Salafy JIhadisme di Indonesia (Depok: Komunitas Bambu, 2011). 
"berdarah" ini hanya diketahui oleh para ahli saja. Sebaliknya, dalam pelajaran sekolah-sekolah para Padri lebih dikenal sebagai pahlawan yang berkorban melawan Belanda. ${ }^{27}$

Oleh karena itu, penulis ingin memberikan catatan penting bahwa istilah perang Padri sendiri tidak hanya mengacu pada perang antara kaum muslim puritan dan kaum muslim yang masih memegang adat saja, akan tetapi lebih dari itu. Ia juga mencakup seluruh peperangan yang terjadi di sekitar Minangkabau dan sekitarnya, terutama di Pagaruyung. Hal ini dibuktikan dengan catatan beberapa peneliti. Sebagaimana dikutip oleh Putri, ${ }^{28}$ bahwa perang Padri terjadi dalam tiga fase. Pertama, fase Padri (1809-1821) sebagai gerakan intelektual pemurnian agama. Kedua, perang Padri (1821-1832) taraf awal dari peperangan melawan pemerintah Belanda. Ketiga, perang Minangkabau (1832-1837) sewaktu masyarakat bersatu melakukan perlawanan terhadap Belanda.

Terlepas dari istilah perang Padri yang melewati berbagai fase, sejarah berbicara bahwa watak gerakan pemurnian agama yang terjadi di tanang Minang ini telah meninggalkan luka bagi masyarakat muslim lainnya yang tidak menerima gerakan pemurnian. Terlebih, kelompok yang dikomandoi Haji Miskin dkk ini merasa bahwa hanya keislaman mereka saja yang murni (sesuai dengan al-Qur'an dan sunnah). Sedangkan model keislaman lain yang masih tercampur dengan budaya setempat-kadang dengan ritual-ritual keagamaan yang sekilas bertentangan dengan ajaran Islam-dianggap sesat, bid'ah lalu patut diperangi. Hal inilah yang menurut hemat penulis adalah embrio gerakan radikal transnasional awal di tanah Nusantara. Gerakan transnasional

\footnotetext{
27 Wahid (ed), Ilusi Negara Islam,76 dan 93.

${ }^{28}$ Putri Citra Hati, 'Dakwah pada Masyarakat Minangkabau: Studi Kasus Pada Kaum Padri', Islamic Communication Journal, 3.1 (2018), 113.
} 
yang dipengaruhi oleh aliran Wahabi periode awal ini pada akhirnya mengusik citra dan model keislaman yang dibawa kaum sufi sebelumnya yang terkenal mampu memadukan budaya setempat dengan Islam tanpa mencerabut budaya setempat dari akarnya.

Dalam perkembangan selanjutnya, ketika Ibnu Saud, Raja Najed yang beraliran Wahabi berhasil menaklukkan Hijaz (Makkah dan Madinah) tahun 1924-1925, beberapa kelompok Islam lain dilarang mengajarkan madzhabnya. Dengan dalih menjaga kemurnian agama, mereka berencana membongkar makam para sahabat dan Nabi. Bahkan, ironisnya banyak ulama' yang berpengaruh di Hijaz dipenjara dan dibunuh oleh penguasa yang berideologi Wahabi ini. ${ }^{29}$ Manuver politik Wahabi ini akhirnya membuat dunia Islam marah. Termasuk di antaranya beberapa ulama' tradisional di Indonesia. Dari sini juga kita mengenal komite Hijaz, sebuah komite diplomasi pertama dari Indonesia. Peristiwa inilah yang menjadi cikal bakal berdirinya NU.

\section{INDONESIA DI TENGAH GEMPURAN IDEOLOGI TRANSNASIONAL}

Sejauh penelusuran penulis, gerakan transnasional yang dibawa oleh Haji Miskin di abad ke 19 tidak begitu berpengaruh dalam model keberislaman masyarakat Indonesia. Terlebih, Indonesia mengalami krisis kemanusiaan (kematian, kelaparan, kemiskinan, diskriminasi) yang disebabkan karena penjajahan Belanda. Meski terkadang terjadi perlawanan, Belanda nyatanya tetap bisa menduduki tahta Indonesia. Oleh karena itu, meskipun $\mathrm{MD}^{30}$ menjadi ormas yang banyak terpengaruh oleh pandangan Muhammad bin Abd Wahab, kelompok ini

${ }^{29}$ Ahmad Mustafa Harun, Menegubkean Islam Nusantara: Biografi Pemikiran dan Kiprah Kebangsaan Prof. KH. Said Aqil Siraj (Surabaya: Khalista, 2015). Hal. 117.

${ }^{30}$ Selanjutnya penulis sebut MD 
tidak menyebabkan perpecahan antara sesama umat Islam yang kiranya berbeda pandangan. Bahkan dalam perkembangan selanjutnya, corak keberislaman MD mulai menghormati aspek-aspek kultural masyarakat, seperti ziarah kubur, shalawatan, dan lain sebagainya.

Hemat penulis, selepas perang Padri masyarakat Indonesia lebih berfokus pada kemerdekaan Indonesia. Sehingga tidak ada gerakan transnasional yang membuat perpecahan bahkan peperangan sesama umat Islam lagi. Keadaan ini terus berlangsung sampai Indonesia akhirnya menyatakan kemerdekaannya dari Belanda dan Jepang pada 17 Agustus 1945, dengan Pancasila sebagai prinsip dasar negara. Pada periode berikutnya, bangsa yang baru tumbuh ini sempat mengalami perdebatan sengit tentang landasan negara yang dipertanyakan kembali. Adanya upaya untuk memasukkan butir-butir Piagam Jakarta yang berbunyi "Ketuhanan dengan kewajiban melaksanakan syariat Islam bagi pemeluk-pemeluknya" akhirnya tenggelam oleh sejarah Indonesia karena "kalah" setelah diuji berkali-kali.

Setelah Soekarno sebagai presiden pertama lengser, Soeharto memimpin negeri ini hampir tanpa adanya ancaman yang berarti"berkat" sikap otoriternya. Bahkan bisa dikatakan masyarakat muslim kurang diperhatikan. Setelah kekuasaan Soeharto diruntuhkan oleh semangat reformasi-khususnya kalangan aktifis muda-keran demokrasi Indonesia pun dibuka. Karena salah satu prinsip demokrasi adalah terbukanya kebebasan publik, maka berbagai ormas baru pun lahir. Di sinilah awal mula gerakan transnasional menapakkan kakinya dan semakin menjamur. Dalam hal ini penulis akan membahas secara singkat tiga gerakan transnasional seperti Hizbut Tahrir Indonesia (HTI), Ikhwanul Muslimin (IM) dan Salafi (Wahabi) dalam konteks Indonesia. 


\section{a. Awal Kemunculan Hizbut Tahrir (HT), Ikhwanul Muslimin (IM) dan Salafi (Wahabi) di Indonesia}

Kelompok pertama yang penulis bahas adalah HTI atau sebelumnya bernama HT (Hizbut Tabrir) adalah partai politik yang berideologi Islam, bukan organisasi kerohanian (seperti tarekat), bukan pula lembaga ilmiah apalagi lembaga sosial. HT menganut Islam sebagai ideologi dan politik sebagai aktifitasnya. HT yang didirikan oleh Taqiyuddin al-Nabhani ${ }^{31}$ di al-Quds, Palestina (1952) ini pertama kali masuk ke Indonesia pada tahun 1982-1983 melalui Abdurrahman al-Baghdadi, pemimpin HT Australia yang kemudian pindah ke Bogor. $^{32}$ Menurut Ismail Yusanto, jubir Hizbut Tahrir Indonesia (HTI), cikal bakal organisasi ini berasal dari negara Yordania. ${ }^{33}$

Agenda utama kelompok ini adalah membangun kembali sistem Khilafah Islamiyah dan menegakkan hukum Islam dalam realitas kehidupan. HT mempunyai cita-cita membangun tatanan masyarakat dan sistem politik berdasarkan landasan akidah Islam. Islam harus menjadi tatanan aturan kemasyarakatan dan menjadi dasar konstitusi dan Undang-Undang. ${ }^{34}$ Agenda HT ini bermula dari anggapannya bahwa umat Islam sekarang hidup dalam Darul Kufr yang serupa dengan kehidupan di masa Nabi Muhammad (saat sebelum hijrah ke Madinah). Dalam melakukan dakwahnya, HT melakukan beberapa tahapan. Pertama, tahap pembinaan dan pengaderan. Kedua, tahapan berinteraksi dengan umat supaya ikut dalam memikul dakwahnya.

31 Abdul Qohar dan Kiki Muhammad Hakiki, 'Eksistensi Gerakan Transnasional HTI Sebelum dan Setelah Pembubaran', Kalam, 11.2 (2017)

32 Masdar Hilmy, 'Akar-akar Transnasionalisme Islam HTI', Islamica, 6.1, (2011), 6.

${ }^{33}$ Tim Aswaja NU Jawa Timur, Khazanah Aswaja: Memahami, Mengamalkan dan Mendakwahkan Ablussunnah Wal Jama'ah (Surabaya: Aswaja NU Center, 2016). Hal. 350.

${ }^{34}$ Imaduddin Rahmad, Arus Baru Islam Radikal (Jakarta: Erlangga, 2005). Hal. 48. 
Ketiga, tahap pengambilan kekuasaan untuk menerapkan Islam secara menyeluruh. ${ }^{35}$

Ismail Yusanto pernah membeberkan bagaimana awal mula HT masuk ke Indonesia. Menurutnya, "Kedatangan HT sebenarnya hampir bersamaan dengan gerakan Islam lainnya seperti Ikhwanul Muslimin, Jama'ah Tabligh dan kelompok salafi lainnya." ${ }^{36}$ Meski HTI telah menyebar ke berbagai negara, dan akhirnya sampai dilakukan pelarangan di berbagai negara (termasuk di Yordania), di Indonesia HTI sempat menjadi organisasi resmi. Nampaknya HTI dapat dengan mudah tumbuh subur di Indonesia. Ini dibuktikan dengan ungkapan Ismail bahwa anggota HTI memiliki anggota terbanyak se-Asia Pasifik. Meski dilarang di beberapa negara, HTI tetap melakukan gerakan underground atau secara sembunyi kepada masyarakat. Demikian juga agenda gerakan, isu yang mereka perjuangkan, hingga kegiatannya sulit untuk diketahui masyarakat umum. ${ }^{37}$ Di sisi lain, HTI berkembang secara pesat di antara komunitas mahasiswa melalui jaringan "dakwah kampus," yang mengalami puncaknya ketikan rezim Soeharto menerapkan pelarangan aktivitas politik mahasiswa melalui Kebijakan Normalisasi Kehidupan Kampus (NKK) tahun 1978. Sejak saat itu, sebagaimana kelompok aktivis Islam lainnya, HTI menjadi gerakan bawah tanah hingga jatuhnya Rezim Orde Baru. ${ }^{38}$

Gerakan transnasional selanjutnya adalah Ikhwanul Muslimin (IM). IM merupakan organisasi Islam yang bergerak di badang dakwah Islam di Mesir dan Dunia Arab. IM sendiri didirikan oleh Hasan al-

\footnotetext{
35 Tim Aswaja, Khazanah, hal. 351.

36 Jamhari dan Jajang Jahroni (Peny), Gerakan Salafi Radikal di Indonesia (Jakarta: Raja Grafindo, 2004). Hal 171.

${ }^{37}$ Rahmad, Arus Baru, hal. 59.

${ }^{38}$ Hilmy, "Akar-akar, hal. 6.
} 
Banna (1906-1949) di Mesir pada tahun 1928. ${ }^{39}$ Di awal pembentukannya, al-Banna sebenarnya sangat memperhatikan aspek pendidikan Islam (tarbiyah Islamiyah). Tujuannya satu, membangun akhlak yang kuat dan akidah yang benar. ${ }^{40}$ Selain itu, IM didirikan alBanna untuk melawan penjajahan Inggris, mengatasi kemunduran Islam dan membawa umat Islam kembali ke ajaran yang murni. Sayangnya, karena watak dasar dari gerakan ini adalah politis yang dikemas dengan busana agama, maka gairah politik tidak bisa lepas dari DNA gerakan ini. Implikasi dari gairah politik ini akhirnya menyebabkan IM sering terlibat konflik dengan penguasa. Puncaknya adalah ketika Hasan al-Banna terbunuh pada tahun $1948 .{ }^{41}$

IM sendiri datang ke Indonesia awalnya melalui lembaga-lembaga dakwah kampus yang kemudian menjadi gerakan Tarbiyah. Bruinessen mengungkapkan bahwa dakwah kampus ini sebenarnya sudah ada di masa Orde Baru tepatnya pada tahun 1978, akan tetapi masih bersifat diam-diam. Kelompok ini baru terbentuk secara resmi pada tahun 1980-an. Di tahun-tahun ini, beberapa kegiatan seperti diskusi grup, pelatihan mental yang diadakan di masjid Salman (ITB) pun akhirnya menginspirasi terbentuknya beberapa gerakan lain. Beberapa Halaqah (diskusi dalam bentuk melingkar) dan juga Usrah (semacam diskusi secara diam-diam) diadakan di rumah salah satu anggota. Materimateri yang didiskusikan biasanya adalah tentang Ikhwanul Muslimin dan tulisan-tulisan al-Maududui. Penekanan diskusi biasanya berkisar tentang moral, kesalehan, kedisiplinan, penolakan dari dalam (inner rejection) terhadap Pancasila, dan juga praktek Indonesia modern yang

\footnotetext{
${ }^{39}$ Abu Za'rur, Seputar Gerakan Islam (Bogor: al-Azhar Press, 2016). Hal. 123.

40 Tim Aswaja, hal. 348-349.

${ }^{41}$ Wahid (ed), Ilusi Negara Islam, hal. 80.
} 
tidak islami. ${ }^{42}$ Kelompok ini kemudian melahirkan Partai Keadilan Sejahtera (PKS). Keterkaitan partai ini dengan IM diakui oleh Mantan Sekretaris Jenderal PKS, Anis Matta. Pendiri partai PKS, Yusuf Supendi pun menyatakan dalam bukunya Replik Pengadilan Yusuf Supendi Menggugat Elit PKS, bahwa nidzom asasi (aturan dasar) partai ini tidak boleh bertentangan dengan aturan IM di Mesir. ${ }^{43}$

Kelompok transnasional ketiga yang penulis bahas adalah Salafi (Wahabi). Aliran Wahabi didirikan oleh muballigh abad 18, Muhammad Ibn Abdul Wahab di Semenanjung Arabia. Impian Abd Wahab adalah membersihkan kerusakan yang diyakininya telah merasuk ke dalam agama. Pada akhir abad ke 18, keluarga Saud bergabung dengan gerakan Wahabi ini dan memberontak pada kekuasaan Ustmaniyah di Jazirah Arab. Namun usahanya ini tidak berhasil karena bala tentara Mesir, Muhammad Ali berhasil memadamkan pemberontakan tersebut. Akan tetapi, Wahabi pantang menyerah. Pada awal abad 20, Abdul Aziz Ibn Saud bergabung dengan pemberontak militan Wahabi yang dikenal kemudian dengan nama ikhwan, pada awal kemunculan Arab Saudi. Pengaruh Wahabi masih terbatas sampai tahun 1970-an, dan ketika harga minyak melambung tinggi, bersama dengan penarikan Saudi yang agresif, secara dramatis aliran Wahabi menyebar di dunia Islam. ${ }^{44}$

Terkait gerakan Salafi dalam konteks Indonesia, sebagaimana penulis sebutkan di awal, gerakan ini pertama kali timbul sejak peristiwa perang Padri di Sumatera Barat. Adapun dalam konteks modern, kiranya pandangan Bruinessen bisa membantu

\footnotetext{
42 Martin van Bruinessen, 'Genealogies of Islamic Radicalism in Post-Soeharto Indonesia', South East Asia Research, 10.2 (2002), 133.

43 Wahid (ed), Ilusi Negara Islam, hal. 78.

${ }^{44}$ Rahmad, Arus Baru, hal. 67.
} 
mempermudah pemahaman kita. ${ }^{45}$ Menurutnya, gerakan Salafi ditransmisikan oleh sekelompok sarjana yang pulang dari Arab Saudi kemudian menyasar kalangan mahasiswa dan sejumlah madrasah. Buinessen menyebut beberapa model Salafi. Pertama, Salafi yang murni yang apolitis dan direstui pemerintah Saudi. Kedua, Salafi politis atau haraki yang muncul akibat persentuhannya dengan gagasan Ikhwanul Muslimin. Ketiga, Salafi Jihadi yang memiliki jaringan dengan al-Qaeda. Bruinessen melanjutkan, menurutnya gerakan Salafi kurang bersentuhan dengan masyarakat hingga setidaknya pada tahun 1999 ketika terjadi konflik antar umat beragama di Maluku. Ketika itu, mereka memobilisasi diri untuk berjihad di sana.

Kehadiran Wahabi modern juga tidak bisa dilepaskan dari peran Dewan Dakwah Islamiyah Indonesia (DDII) yang diketuai Moh Natsir. Tujuan didirikannya DDII juga memiliki tujuan tersendiri, yakni untuk menahan gerak laju gerakan pembaharuan yang berorientasi pada sekularisme. ${ }^{46}$ Dengan dukungan dana besar dari Jamaah Salafi (Wahabi), DDII mengirimkan mahasiswa untuk belajar ke Timur Tengah, sebagian dari mereka lah yang akhirnya menjadi agen-agen penyebaran ideologi Wahabi-Ikhwanul Muslimin di Indonesia. Belakangan, dengan dukungan penuh dari Wahabi-Saudi pula, DDII mendirikan LIPIA dan kemudian kebanyakan alumninya kemudian menjadi agen Gerakan Tarbiyah dan Jamaah Salafi Indonesia. Dibandingkan dengan HTI, Wahabi memang lebih dekat dengan Ikhwanul Muslimin. Kedekatan ini berawal pada dekade 19501960-an ketika Gamal Abdel Nasser membubarkan Ikhwanul Muslimin yang ekstrim dan melarang semua kegiatannya di Mesir.

\footnotetext{
45 Ahmad Khoirul Fata dan Moh. Nor Ikhwan, 'Pertarungan Kuasa dalam Wacana Islam Nusantara', Islamica: Jurnal Studi Keislaman, 11.2 (2017), 350.

${ }^{46}$ Fata, 'Pertarungan Kuasa', hal. 351.
} 
Banyak tokoh-tokoh Ikhwanul Muslimin yang akhirnya melarikan diri dari negaranya. ${ }^{47}$

Dari uraian tentang ketiga gerakan di atas, ada gambaran umum yang sepatutnya digaris bawahi, bahwa ketiganya, meskipun memiliki latar sejarah yang berbeda, bisa dikatakan saling bahu membahu dalam mencapai tujuan mereka, yakni formalisasi Islam dalam bentuk negara, aplikasi syariah sebagai hukum positif dan perjuangan Khilafah Islamiyah.

\section{b. Transformasi IM, HTI dan Salafi setelah Reformasi-Sekarang}

Tulisan terbaru yang mencoba melacak bahaya gerakan Islam transnasional baru-baru ini semisal, NU di Tengah Pusaran Ideologiideologi Transnasional (2018) yang ditulis oleh Zainul Mu’ien Husni. Menurutnya kelompok Salafi masih menggunakan pendekatan personal sampai dakwah terbuka di atas mimbar. Di samping itu, dengan memanfaatkan potensi dana yang digelontor dari negara asalnya, Arab Saudi, mereka menerbitkan buku-buku, buletin dan majalah yang didistribusikan secara cuma-cuma, serta membangun stasiun-stasiun televisi dan radio di berbagai daerah strategis. Daya tarik mereka, terutama di kalangan pemuda kampus, terletak pada pemaparan dalil-dalil atas setiap klaim yang mereka sampaikan.

Sedangkan kelompok HTI terus mempropagandakan ideologinya kepada para mahasiswa melalui diskusi-diskusi ilmiah dan forumforum dalam kegiatan ekstrakulikuler. Mereka juga rajin menerbitkan media cetak mulai dari buletin, majalah dan buku-buku. Sementara itu di luar kampus mereka juga proaktif melakukan pendekatan terhadap

${ }^{47}$ Wahid (ed), Ilusi Negara Islam, hal. 78. 
masyarakat awam secara personal dan melalui kelompok-kelompok kegiatan yang ada di desa-desa. ${ }^{48}$ Akan tetapi, hemat penulis Zainul belum memberi gambaran tentang fenomena gerakan transnasional terbaru. Ia hanya memberikan gambaran umum bahwa kelompok seperti HTI (meski telah dibubarkan) dan Salafi masih menyebarkan paham mereka dengan berbagai cara.

Tulisan lain yang patut untuk dijadikan rujukan penting dan bisa menjadi gambaran terbaru eksistensi HTI setelah dibubarkan pada tahun 2017 adalah tulisan Abdul Qohar dan Kiki M. Hakiki. Keduanya menyimpulkan—meski masih bersifat asumsi-bahwa selepas HTI dibubarkan, ada dua langkah yang dilakukan: Pertama, pembentukan ormas baru pengganti HTI. Kedua, menjadi partai baru atau beralih haluan dan bergabung kepada partai berbasis Islam yang sudah ada. Mereka akan mencari partai-partai yang secara ideologi sama atau mirip dengan ideologi HTI sebelumnya, seperti PKS, PPP, PAN dan PBB. Kondisi ini akan terjadi jika mereka gagal memperjuangkan dan mempertahankan ideologinya dalam bentuk ormas. ${ }^{49}$

Satu hal yang perlu dijadikan catatan bagi pemerintah Indonesia adalah bahwa membubarkan sebuah organisasi tidak serta merta dapat menghilangkan ideologi yang telah tertancap lama para penganutnya, apalagi para pengagum HTI sudah bisa dikatakan banyak. Maka dari itu, perlu ada semacam regulasi yang benar-benar tidak terkesan represif dan melawan nilai demokrasi, di sisi lain, kedua ormas terbesar (MD dan NU) juga harus bahu membahu melawan gerakan transnasional. Syukur-syukur nilai moderat yang dipegang dua ormas ini semakin diinternasionalisasikan.

\footnotetext{
${ }^{48}$ Husni, 'NU di Tengah Pusaran', hal. 56.

${ }^{49}$ Qohar, 'Eksistensi Gerakan'.
} 


\section{SELAYANG PANDANG ORMAS ISLAM TERBESAR DI INDONESIA: MUHAMMADIYAH DAN NADLATUL ULAMA'}

\section{a. Sejarah Singkat dan Karakter Muhammadiyah}

Sebelum NU dan MD lahir di Indonesia, dalam belahan dunia lain, yakni Mesir telah melahirkan segudang pembaharu Islam. Kesadaran akan pembaharuan ini juga dipengaruhi oleh Napolen Bonaparte yang kala itu datang ke Mesir dengan membawa peradaban baru. Akhirnya, lahirlah tokoh-tokoh pembaharu mesir seperti Muhammad Abduh, al-Tahtawi, al-Afghani dll. Pengaruh Abduh tidak hanya melanda orang-orang tertentu. Lebih dari itu, ia juga sangat berpengaruh dalam berdirinya ormas Islam terbesar ke dua di Indonesia setelah NU, yakni MD. Organisasi yang berwatak modernis $^{50}$ ini didirikan pada tahun 1912 oleh Ahmad Dahlan. Ia mengikuti pemikiran Muhammad bin Abdul Wahab dalam menentang takhayul, bid'ah dan khurafat. Selain MD, terdapat ormas-ormas lain yang lahir di waktu yang hampir bersamaan. Seperti al-Irsyad (1913), Persis (1920-an). Ketiganya memiliki kesamaan dalam sikap keberagamaannya yang skriptualis. Namun demikian, sebagaimana disinggung sebelumnya, dari ormas-ormas ini Muhammadiyah sepertinya mengalami perbuahan sikap yang semula sangat konfrontatif terhadap tradisi lokal, di era kontemporer sekarang banyak yang menilai bahwa model keberagamaan MD dikatakan lebih lunak. ${ }^{51}$

${ }^{50}$ Istilah modernis sebagai kebalikan dari tradisionalis di sini digunakan untuk membedakan antara MD dan NU.

${ }^{51}$ Mujamil Qomar, Fajar Baru Islam Indonesia (Bandung: Mizan, 2012). Hal. 96-97. 
Nampaknya para peneliti sepakat bahwa meskipun MD memiliki karakter yang begitu keras dalam mengkritik tradisi lokal dengan gerakan pemurniannya (puritanisme), namun para ulama' MD tidak pernah menggunakan sisi kekerasan dalam memaksakan pemahaman agamanya. Sebagaimana keterangan di atas bahwa watak puritanisme Muhammadiyah mengalami dinamika yang cukup panjang. Di sisi lain, sebagai ormas Islam yang lahir dari "dalam diri” Indonesia, Muhammadiyah tidak hanya disibukkan dengan pemurnian ajaran. Sebaliknya, mereka juga fokus pada bidang-bidang lain seperti pendidikan dan sosial dalam rangka memajukan bangsa Indonesia.

\section{b. Sejarah Singkat dan Karakter Nahdlatul Ulama'}

Pada tahun 1925, Raja Sa'ud menguasai Arab Saudi dan menjadikan Wahabi sebagai ajaran agama resmi negara. Untuk memperkuat "powernya" sebagai penguasa tertinggi di Hijaz, ia berencana mengadakan World Islamic Congress di Mekah pada tahun 1926. ${ }^{52}$ Menanggapi fenomena yang terjadi di Saudi inilah akhirnya pada tanggal 31 Januari 1926, rumah Wahab Chasbullah (1888-1971) di Kertopaten, Surabaya didatangi sekitar 15 orang kiai. Sebagian mereka datang dari Jawa Timur dan masing-masing adalah tokoh pesantren. Dalam kesempatan ini mereka memikirkan bersama bagaimana nasib Islam tradisional yang mereka praktekkan. Setelah diskusi yang cukup alot, muncullah kata sepakat untuk mendirikan NU (Nahdlatul Ulama'). Tujuan jangka pendek dari perkumpulan ini adalah mensahkan terbentuknya Komite Hijaz yang akan mengirim delegasi ke Mekah untuk mempertahankan praktek-praktek keagamaan yang dianut kaum tradisionalis, seperti kebebasan

52 Robin Bush, Nabdlatul Ulama' and the Struggle for Power within Islam and Politics in Indonesia (Pasir Panjang: ISEAS, 2009). Hal. 34. 
bermadzhab dan ritual lainnya. Sedangkan tujuan panjangnya adalah menciptakan suatu lembaga yang mampu mengkoordinasikan dan respon kaum tradisionalis terhadap ancaman kaum modernis. Selanjutnya, dipilihlah Hasyim Asy'ari sebagai ketua Syuriah, seorang ulama' yang paling disegani di antara para pendiri. ${ }^{53}$ Sedangkan Hasan Gipo, yang bukan merupakan ulama', sebagai ketua Tanfidziyah.

Dalam Analisa Bruinessen, dua bentuk kepemimpinan dalam diri NU (Syuriah dan Tanfidziyah) menjadi sumber munculnya konflik. Hal ini karena tidak jarang pandangan Tanfidziyah (yang kebanyakan diwakili oleh orang awam) berbeda dengan pandangan Syuriah (yang kebanyakan diisi para ulama'). Perbedaan pandangan inilah yang mengiringi sejarah NU selanjutnya, perbedaan ini pula yang akhirnya melahirkan istilah "kembali ke khittah 26". ${ }^{44}$

\section{c. Dua "Sahabat" yang Sempat "Bertikai"}

Membahas MD dan NU tidak boleh lepas dari sejarah perjalanan dan perkembangan keduanya. Kenapa demikian? Karena dinamika keduanya panjang. Kurang tepat—dalam konteks sekarang—apabila orang berkata bahwa kelompok MD itu tetap puritan dan sering membid'ahkan kalangan NU. Sedangkan di sisi lain juga menganggap bahwa kalangan NU ini tetap kolot dan tidak mau menerima perubahan.

"Pertikaian" antara NU dan MD diakui banyak pihak hanya sebatas dalam ranah furu'iyah atau cabang dalam bidang agama. Misalnya, di awal pembentukan kelompok modernis (MD), kaum dan 33 .

${ }^{53}$ Greg Fealy, Ijtihad Politik Ulama’: Sejarah NU 1952-1967 (Yogyakarta: Lkis, 2003). Hal. 21

${ }^{54}$ Bush, Nahdlatul Ulama', hal. 36. 
tradisionalis $(\mathrm{NU})$ menganggap bahwa kemunculannya mengancam praktek-praktek dan kepercayaan yang telah menjadi bagian dari keberagamaan kaum tradisionalis. Termasuk di antaranya tradisi pembacaan doa bagi orang meninggal, ziarah kubur dan pembacaan lafadz ushalli sebelum sholat. Kalangan MD menganggap bahwa beberapa praktek di atas tidak diajarkan di dalam al-Qur'an, bentuk sakralisasi tradisi lokal dan bahkan sebuah ritual sebelum datangnya Islam. Karena itu, kaum modernis menganggapnya sebagai perilaku bid'ah. Konflik antara keduanya juga biasanya juga disebabkan karena persoalan taqlid dan ijtihad, sebagaimana disinggung di awal.

Meski kebanyakan ahli melihat pertikaian di antara keduanya disebabkan karena faktor agama, tidak demikian menurut Robin. Menurutnya, faktor sosio-kultural juga sangat menentukan. Kebanyakan kaum tradisional adalah seorang petani yang tinggal di desa. Mereka juga terikat oleh politik kepemilikan tanah. Di sisi lain, kaum modernis yang kebanyakan hidup di perkotaan adalah seorang intelektual, profesional dan birokrat. Dua perbedaan latar belakang sosial inilah yang secara tidak langsung mempengaruhi dua kelompok di atas. Masyarakat muslim yang tinggal di pedesaan (pedalaman) sangat dekat dengan birokrasi agama tradisional dan elit aristokrat. Adapun masyarakat muslim yang hidupnya di perkotaan dan pesisir kurang tertarik untuk menjaga struktur elit di atas. Sebaliknya, mereka secara teologi lebih cenderung puritan dan reformis. Karena itu, perbedaan doktrin agama, sosial dan ekonomi telah memperkeras (solidify)perbedaan antara muslim tradisional dan modernis. ${ }^{55}$

Feally berpendapat lain, menurutnya penyebab pertikaian keduanya adalah karena faktor ekonomi dan materi. Dalam analisa

${ }^{55}$ Bush, Nahdlatul Ulama', hal. 33. 
Feally, sekitar tahun 1910-an, meski dua kelompok ini berbeda namun tetap menghormati. Akan tetapi, ketika masuk tahun 1920-an, persoalan material membuat hubungan keduanya memburuk. Pada tahun-tahun ini, kaum modernis mempertajam kritikannya terhadap kiai, mereka menantang otoritas seorang kai yang dianggap tidak pernah salah (infalliably). Kenyataan ini diperparah dengan ekspansi kaum modernis ke berbagai kota di Jawa Timur dan Jawa Tengah yang mana mengancam basis ekonomi banyak pesantren dan ekonomi keluarga kiai yang mengendalikannya. ${ }^{56}$ Karena itu, meski isu keagamaan dan ritual menjadi inti perbedaan antara kaum modernis dan tradisionalis, pertikaian di antara keduanya tidak tercipta sampai akhirnya isu ekonomi dan teritorial mengemuka.

Terkait dengan perkembangan MD dalam dua dasawarsa terakhir menarik untuk dituangkan di sini. Dalam penelitian lapangan di desa Wuluhan Jember, Jawa Timur yang dilakukan Abdul Munir Mulkhan dengan judul Islam Murni dan Masyarakat Petani (2000) disimpulkan bahwa terdapat kategori warga MD, yaitu "Muhammadiyah ikhlas" yang memiliki tendensi puritan yang kuat; Muhammadiyah Ahmad Dahlan, yang memiliki karakter moderat dan tetap berpegang pada norma organisasi Muhammadiyah, Muhammadiyah Nahdlatul Ulama' (MUNU), yang masih mengadopsi singkretik dan dominan dalam pola peribadatan kaum tradisionalis, dan Marhaenis-Muhammadiyah (MARMUD), yakni warga MD yang memiliki pandangan politik kekiri-kirian, pengagum Soekarno dan juga punya orientasi politik nasionalis-sekuler yang kuat. Hilman Latief (Peneliti muda MD),

${ }^{56}$ Fealy, Ijtihad Politik, hal. 31. 
dalam Post Puritanisme (2017), ${ }^{57}$ berpendapat bahwa fleksibilitas dan moderasi MD akan benar-benar diuji ketika berada dalam lingkungan masyarakat Kristen yang dominan.

Dari sejarah dan perkembangan singkat kedua ormas Islam terbesar di atas, bisa tergambar perbedaan karakter dari keduanya. Yang pertama (MD) lebih berwatak modernis dan puritan dengan misalnya menentang bid'ah, khurafat dan menjunjung tinggi aspek tajdid. Adapun yang kedua (NU) lebih cenderung mengakomodir nilainilai tradisional sebagai bentuk peninggalan sekaligus kekayaan Indonesia, karena itu tidak dianggap bertentangan dengan agama. Perbedaan karakter antara keduanya dari tahun ke tahun tidak berjalan statis, akan tetapi dinamis. Dalam arti, dewasa ini kelompok Muhammadiyah melaksanakan tradisi yang dilakukan NU, dan di sisi lain NU juga mengimplementasikan semangat tajdid dari MD. Bahkan banyak pengamat menilai bahwa para pemuda NU era sekarang lebih maju dan berani "menabrak" tradisi lama dibanding pemuda MD.

\section{ISLAM NUSANTARA BERKEMAJUAN: PERJUANGAN MODERASI DI TENGAH PUSARAN IDEOLOGI TRANSNASIONAL}

Corak keislaman NU dan MD yang bersifat moderat memang sudah tidak diragukan lagi. Di samping menjadi acuan sebagian besar umat Islam Indonesia, keduanya juga menjadi garda terdepan dalam menjaga keutuhan NKRI (Negara Kesatuan Republik Indonesia). Hal ini menjadi lebih nyata saat keduanya secara tegas mendukung Pancasila sebagai ideologi pengikat keberagaman bangsa Indonesia. Sejarah

${ }^{57}$ Hilman Latief, Post Puritanisme: Pemikiran dan Arah Baru Gerakan Islam Modernis di Indonesia 1995-2015 (Yogyakarta: LP3M UMY, 2017). Hal. 11. 
panjang perdebatan landasan negara Indonesia begitu menarik untuk dilihat kembali. Karena sesaat setelah Indonesia mereka, jangan dibayangkan bahwa semua pendiri bangsa sepakat menjadikan Pancasila sebagai dasar negara. Dalam kenyataannya, beberapa tokoh muslim menginginkan Islam sebagai dasar negara, baik dari perwakilan NU (A. Wahid Hasyim) maupun perwakilan MD (Ki Bagus Hadikusumo). ${ }^{58}$ Akan tetapi, kebesaran jiwa para pendiri bangsa disertai wawasan luas tentang prospek ke depan bangsa Indonesia, akhirnya mereka menyetujui Pancasila sebagai landasan bangsa, bukan Islam atau tujuh kata yang akhirnya dicoret dalam Piagam Madinah. ${ }^{59}$ Karena mereka melihat bahwa nilai-nilai Islam sudah tercermin dalam kelima sila Pancasila.

Tantangan Indonesia sekarang tentu berbeda dengan tantangan Indonesia pasca kemerdekaan. Dalam konteks hubungan negara dan agama, masih ada saja sekelompok golongan yang mencoba mengganti landasan Pancasila maupun sistem demokrasi sebagai alat yang sejauh ini efektif untuk menciptakan keadilan sosial bangsa Indonesia. Kelompok yang datang dari luar atau transnasional inilah yang menjadi tantangan nyata bagi keutuhan Indonesia. NU dan MD sebagai ormas yang telah merasakan asam garamnya memperjuangkan kemerdekaan Indonesia tentu tidak "rela" tali persaudaraan dan kebinekaan Indonesia yang mereka rajut sekian lamanya runtuh seperti negara-negara Timur Tengah. Karena itu, melihat peran mereka dalam menghadapi tantangan Islam transnasional yang mengusung ide-ide khilafah dan syariat Islam secara radikal penting untuk dikemukakan. Seperti apa sikap kedua ormas ini,

\footnotetext{
58 Pertemuan-pertemuan BPUPKI saat itu dilaksanakan antara Mei sampai Agustus 1945. Lihat Bahtiar Effendi, Islam dan Negara: Transformasi Gagasan dan Praktik Politik Islam di Indonesia.terj (Demokrasi Project, 2011). Hal. 97-99.

59 Pimpinan Pusat Muhammadiyah, Tanfidz. Keputusan Muktamar Muhammadiyab ke-47 (Yogyakarta: Gramasurya, 2015). Hal. 65. 
khususnya kepada ketiga gerakan Islam transnasional yang penulis kemukakan, seperti HTI, IM dan Salafi?

Untuk menjawab pertanyaan di atas, penulis berusaha melacak beberapa data (baik jurnal, buku, koran, situs resmi keduanya) yang secara khusus menampilkan peran dan tindakan MD maupun NU baik secara organisasional maupun secara personal, yakni para tokoh-tokoh dari kedua ormas tersebut dalam meng-counter gerakan transnasional.

Muktamar ke-33 di Jombang tahun 2015 nampaknya menjadi upaya serius NU dalam menyikapi berbagai paham atau ideologi transnasional yang sedang "mengepung" tanah air. Tema besar yang diangkat kala itu adalah "Meneguhkan Islam Nusantara untuk Membangun Peradaban Indonesia dan Dunia". ${ }^{60}$ Karenanya, Said Aqil Siraj sebagai ketua dengan percaya diri menjelaskan konsep Islam Nusantara sebagai Islam khas Indonesia. Menurutnya, Islam Nusantara menurutnya bukan mazhab, bukan aliran, tapi tipologi, mumayyizaat dan khashais. Islam Nusantara juga bukan Islam yang anti-Arab dan Islam yang benci Arab. Akan tetapi Islam yang santun, berbudaya, ramah, toleran, berakhlak, dan berperadaban. ${ }^{61}$ Hemat penulis, upaya Said Agil sebagai ketua PBNU sudah sangat tepat dan ini merupakan salah satu "stategi" NU, mengingat wajah keislaman Indonesia yang moderat sedang dipertaruhkan.

Tanggapan pro dan kontra terhadap istilah Islam Nusantara pun akhirnya mencuat. HTI, PKS dan FPI sebagai perwakilan dari ormas yang mempunyai afiliasi dengan Salafi dan doktrin pemurnian (purify) Islam secara terang-terangan menolak istilah ini. ${ }^{62}$ Sebaliknya, tanggapan

\footnotetext{
${ }^{60}$ https://news.detik.com/berita/2980904/presiden-jokowi-apresiasi-tema-muktamar-ke-33nu-islam-nusantara diakses pada 30-10-2019.

${ }^{61}$ https://www.nu.or.id/post/read/66603/kang-said-agar-tak-salah-paham-islam-nusantarabertabayunlah-ke-pbnu diakses pada 30-10-2019.

${ }^{62} \mathrm{https://www.bbc.com/indonesia/berita} \mathrm{indonesia/2015/06/150614} \mathrm{indonesia} \mathrm{islam} \mathrm{nus}$ antara diakses pada 31-10-2019.
} 
apresiatif muncul dari tokoh Muhamadiyah, Azyumardi Azra. Menurutnya, tema besar Muktamar ke-33 NU sangat relevan dan tepat waktu dalam konteks nasional maupun internasional. Menurutnya, ortodoksi Islam Nusantara berbeda dengan ortodoksi Islam Arab Saudi. Ortodoksi Islam Arab Saudi mengandung hanya dua unsur, yaitu pertama, kalam (teologi) Salafi-Wahabi dengan pemahaman Islam literal dan penekanan pada Islam yang 'murni'. ${ }^{63}$

Melalui akun resmi NU Online, penulis mendapatkan beberapa hasil muktamar NU ke-33 yang penting untuk dikemukakan. Dijelaskan bahwa NU sekarang sedang menghadapi masalah yang sangat kompleks, termasuk di antaranya ancaman terhadap ideologi/paham/ajaran yang diyakini dan dianut oleh warga/jamaah NU. Berbagai kelompok aliran ideologi Islam transnasional memandang sesat terhadap praktek tradisi dan amaliah NU yang selama ini dilakukan oleh warga NU, juga terhadap beberapa pokok ajaran dan akidah Islam Aswaja (Ablussunnah Waljama'ah) yang dianut NU. Berbagai cara yang dilakukan untuk menyerang praktek amaliah maupun ajaran NU tersebut diantaranya melalui media cetak maupun elektronik, diskusi maupun seminar-seminar dan kegiatan dakwah lainnya. Dampak dari gerakan yang mengatasnamakan pemurnian ajaran Islam tersebut, membuat warga nahdliyyin resah bahkan ragu terhadap apa yang selama ini dilakukan. Kegamangan, keraguan dan bahkan beberapa di antara warga meninggalkan amaliah NU dan ajaran Islam Aswaja selain karena faktor dari luar juga faktor dari diri mereka sendiri yaitu kurangnya pemahaman tentang dasar-dasar praktek tradisi ataupun amaliah NU demikian juga

${ }^{63}$ https:/ / www.republika.co.id/berita/kolom/resonansi/15/06/17/nq3f9n-islam-nusantara1 diakses 30-10-2019. 
tentang Islam Aswaja. Yang demikian juga karena kurangnya bimbingan dari para pemimpin, tokoh maupun pengurus NU kepada mereka.

Untuk menjawab persoalan di atas, NU sebagai jam'iyah memprioritaskan agar menguatkan kembali pemahaman kepada warga NU terhadap dasar-dasar rujukan tradisi dan amaliah NU, sekaligus menyebarluaskan ajaran Islam Aswaja. Penguatan tentang Aswaja di lingkungan internal NU ditujukan bagi para pengurus NU, kader maupun jama'ah NU di seluruh penjuru tanah air termasuk mereka yang berada di daerah terpencil maupun daerah transmigrasi. Adapun penguatan di lingkungan eksternal ditujukan kepada pihak-pihak diluar NU baik yang berada di dalam maupun di luar negeri. Penyebaran Aswaja ini dimaksudkan untuk memperluas dan memperbanyak masyarakat yang pada dirinya tumbuh dan berkembang karakter dalam cara berfikir, bersikap dan bertindak dalam kehidupan sehari-hari atas dasar nilai-nilai; Tawassuth (moderat), Tawazun (seimbang) dan Tasamuh (toleran), dalam rangka mewujudkan perdamaian, ketentraman sesama umat dalam kehidupan bermasyarakat maupun bernegara serta berbangsa. ${ }^{64}$

Terlihat jelas upaya NU untuk memperkuat barisan Nahdliyyin agar tidak "kecolongan lagi" oleh kelompok transnasional yang selalu mengancam. Isu penyusupan kelompok-kelompok garis keras transnasional dari Timur Tengah (HTI-Ikhwanul Muslimin dan Hizbut Tahrir) ini sebenarnya telah menjadi pembicaraan yang santer di kalangan nabdliyyin. Salah satu alasan kelompok Islam garis keras sering menuduh masjid-masjid NU mengajarkan bid'ah dan aliran sesat adalah untuk merebut masjid-masjid tersebut. Tuduhan itu pun akhirnya membuat

${ }^{64}$ Rumadi, dkk (ed), Hasil-hasil Muktamar ke-33 Nabdlatul Ulama', cet. 2 (Jakarta: Lembaga Ta'lif wan Nasyr PBNU, 2016). Hal. 340. 
Lembaga Dakwah Nahdlatul Ulama' (LDNU) mengeluarkan maklumat berisi peneguhan kembali ajaran Ahlussunnah Wal Jama'ah. ${ }^{65}$

NU bukan satu-satunya ormas yang geram, karena di tengahtengah MD sendiri pernah terdapat diskursus mendalam tentang infiltrasi ajaran transnasional dalam tubuh MD. Sinyalemen tersebut semula disampaikan oleh Abdul Munir Mulkhan pada tahun 2005 dengan menulis keprihatinannya dalam Suara Muhammadiyah. "Sendang Ayu: Pergulatan Muhammadiyah di Kaki Bukit Barisan". Farid Setiawan membicarakan infiltrasi garis keras ke dalam Muhammadiyah secara lebih luas dalam dua artikel di Suara Muhammadiyah, "Ahmad Dahlan Menangis" yang merupakan tanggapan terhadap Tulisan Abdul Munir Mulkhan dan "Tiga Upaya Mu"allimin dan Mu"allimat," Haidar Nashir mengklarifikasi isu-isu dimaksud dalam sebuah bukunya yang berjudul "Manifestasi Gerakan Tarbiyah: Bagaimana Sikap Muhammadiyah?"

Gerakan garis keras dan kaki tangannya sebenarnya telah lama melakukan infiltrasi ke Muhammadiyah. Dalam muktamar MD tahun 2005 di Malang, para agen kelompok transnasional seperti HTI dan PKS mendominasi banyak forum dan berhasil memilih beberapa simpatisan gerakan garis keras menjadi ketua PP. Muhammadiyah. Namun setelah Abdul Munir Mulkhan mudik ke desa Sendang Ayu, Lampung, masalah infiltrasi ini menjadi sebuah kontroversi besar nasional bahkan internasional. ${ }^{66}$ Puncak dari kontroversi ini, khususnya setelah buku Haidar terbit, adalah diterbitkannya Surat Keputusan Pimpinan Pusat (SKPP) Muhammadiyah Nomor 149/Kep/1.0/B/2006. SKKP ini mempunyai tujuan utama untuk "menyelamatkan MD dari berbagai

${ }^{65}$ Terkait poin-poin maklumatnya, silahkan lihat Wahid (ed), Ilusi Negara Islam, hal. 190-191.

66 M. Anas Fakhruddin, "Kontra Ideologi Terorisme menurut Nahdlatul Ulama' dan Muhammadiyah di Lamongan" Jurnal Review Politik, 7.1 (2017), 190-191. 
tindakan yang merugikan Persyarikatan". Ada sepuluh butir poin yang dianggap merugikan MD, yang secara garis besar tindakan yang merugikan itu adalah infiltrasi di tubuh MD dari organisasi lain yang memiliki paham, misi dan kepentingan yang berbeda dari MD. ${ }^{67}$

Perkembangan terakhir tentang sikap Muhammadiyah tercermin dalam Muktamar ke-47 yang berlangsung di Makassar, Sulawesi Selatan (2015). Tema yang diangkat adalah "Dakwah Pencerahan Menuju Indonesia Berkemajuan". Salah satu hal penting yang dibahas di dalamnya adalah tentang komitmen MD untuk menjaga dasar negara Pancasila dan Indonesia sebagai Darul 'Abdi Wassyahadah, negara kesepakatan dan kesaksian. Dalam pidatonya, Din Syamsudin menyampaikan bahwa "Gerakan Pencerahan Menuju Indonesia Berkemajuan" akan menunjukan sikap batin MD kepada negara yang tidak perlu diragukan lagi, sebab MD ikut terlibat bersama elemenelemen bangsa lain di dalam menengakkan negara. Tema ini juga menunjukkan sikap komitmen MD kepada pemerintah yang sah bahwa pemerintah adalah mitra strategis Muhammadiyah. Meski isu-isu Islam transnasional tidak menjadi salah satu pembahasan khusus, Din tetap mengingatkan bahwa MD sedang menghadapi apa yang ia sebut sebagai "arus silang". Maksudnya, ada orang-orang, kelompok-kelompok di antara kita yang ingin melakukan tajridisasi mu'amalat, ujungnya jumud, konservatif, eksklusif. Tapi juga ada pihak seberang yang seharusnya tajdid di bidang kebudayaan tadi melakukan tajdidisasi aqidah dan ibadah, itu ujungnya liberal..$^{68}$

${ }^{67}$ Wahid (ed), Ilusi Negara Islam, hal. 179.

${ }^{68}$ Muhammadiyah, Tanfidr, hal. 139 dan 152. 


\section{KONTRIBUSI KEDUANYA DALAM MENYUARAKAN MODERASI BERAGAMA DI PANGGUNG DUNIA}

Delphin Alles dalam Transnational Islamic Actors an Indonesia's Foreign Policy. ${ }^{69}$ Mengatakan bahwa muktamar ke-33 (NU) dan ke-47 (MD) tersebut mengandung pesan yang sangat jelas bahwa kedua ormas terbesar di Indonesia ini tidak lagi hanya sekedar devensive dalam menghadapi model keislaman transnasional dari berbagai "arah". Akan tetapi keduanya-meski dengan model yang berbeda—sudah mulai menginternasionalisasi (internationalization) ciri keislamannya ke panggung dunia. Ambisi keduanya inilah yang mempengaruhi kebijakan luar negeri Indonesia untuk terus memperkenalkan Indonesia sebagai "rumah" bagi Islam moderat dan sebagai contoh kehidupan yang harmoni di tengah berbagai keyakinan yang ada.

Dalam pembahasan ini penulis tidak hanya melihat peran NU dan MD saja dalam memperkenalkan corak Islam Indonesia yang moderat kepada dunia, akan tetapi juga peran keduanya Indonesia secara keseluruhan. Terlebih, pandangan-pandangan tokoh nasional sebagai insider maupun tokoh luar sebagai outsider menjadi penting untuk menilai peran Indonesia di panggung dunia.

Terlebih dahulu kita membahas tentang peran MD dalam menginternasionalisasi perannya di panggung dunia. Hilman menganggap bahwa bila dibandingkan dengan beberapa organisasi Islam transnasional saat ini, ruang lingkup gerak MD masih bersifat regional. Hal ini senada dengan kritik Van Bruinessen, bahwa Islam Indonesia masih kurang percaya diri dan lemah dalam daya ekspansinya ke luar negeri.

${ }^{69}$ Delphine Alles, Transnational Islamic Actors an Indonesia's Foreign Policy (New York: Routledge, 2016). Hal. 1. 
Kelemahan peran Internasional inilah yang sejak beberapa tahun terakhir coba ditutupi Din Syamsuddin (selaku Ketua Umum) kala itu. Selain secara pribadi aktif dalam berbagai pertemuan internasional, ${ }^{70}$ ia juga mengajak MD keluar dari lingkup keindonesiaan dan menjadi gerakan yang mengglobal. Beberapa hal yang Din lakukan misalnya mendorong pendirian PCIM (Pimpinan Cabang Istimewa Muhamadiyah) di berbagai negara, mendorong kerjasama luar negeri bagi berbagai amal usaha Muhammadiyah, ikut berperan aktif dalam penciptaan perdamaian di Tailand Selatan dan juga memberikan pemuda-pemuda di negeri itu beasiswa di berbagai perguruan tinggi Muhammadiyah. ${ }^{71}$ Lalu bagaimana dengan kipran dan peran NU?

Kiprah NU untuk dunia bisa dilacak melalui upaya-upayanya dalam mendorong perdamaian dunia dan menghilangkan imperialisme di tanah Palestina, selai itu NU juga gencar dalam memperkenalkan ciri khas Islam Nusantara ke berbagai pemimpin dunia. Terkait dengan isu Palestina, PBNU (Pengurus Besar Nahdlatul Ulama') telah melakukan berbagai upaya seperti mendorong warga Palestina untuk terus memperjuangkan kemerdekaannya, mendesak PBB agar memasukkan Palestina sebagai anggota resmi, mendesak agar OKI (Organisasi Kerjasama Islam) untuk secara intensif mengorganisir anggotanya untuk mendukung kemerdekaan Palestina. Terkait isu Rohingya, NU mendesak kepada Pemerintah Myanmar memulihkan hak warga Rohigya yang terusir untuk kembali sebagai warga negara yang setara. Adapun terkait

${ }^{70}$ Din ikut berperan dalam mempromosikan interaksi antar pemerintah Jepang dengan Islam. Ia juga telah membantu Jepang untuk mensosialisasikan makanan halal di Jepang. Ia pun mendapatkan gelar "The Order of Rising Sun, Gold, and Silver Star" dari Kaisar Akihito pada tahun 2018. http://www.muhammadiyah.or.id/id/news-15250-detail-din-kembali-terima-gelar-kehormatan-daripemerintah-jepang.html diakses pada 31-10-2019.

71 Ahmad Najib Burhani, Internasionalisasi Mubammadiyab: Agenda Promodi Pemikiran dan Gerakan, dalam Islam Berkemajuan untuk Peradaban Dunia (Bandung: Mizan Pustaka, 2015). Hal. 252256. 
isu ISIS, NU mendesak masyarakat internasional untuk memerangi ISIS dan mencegah transnasionalisasi ideologi kekerasan di seluruh dunia. ${ }^{72}$

Selain upaya-upaya yang telah dilakukan PBNU, secara personal tokoh-tokoh NU juga cukup dikenal dunia dan mempunyai pengaruh besar. Hal ini bisa dilihat dari daftar muslim berpengaruh yang baru-baru ini telah dirilis dalam The Muslim 500: The World's 500 Influental Muslims (2020). ${ }^{73}$ Meski tokoh-tokoh yang masuk dalam rilis RISSC (The Royal Islamic Strategic Studies Centre) ini tidak selalu berhaluan moderat, akan tetapi terpilihnya tokoh-tokoh seperti Presiden Joko Widodo (urutan ke13), Said Aqil Siraj (urutan ke-19) dan Habib Luthfi bin Yahya (urutan ke-33) dalam daftar 50 besar-dalam konteks ini tidak hanya mewakili Indonesia, tetapi juga NU—-selama tiga tahun berturut-turut bahkan ada kecenderungan pengaruhnya naik bisa menjadi sinyalemen positif bahwa tokoh-tokoh ini tidak bisa dipandang sebelah mata oleh masyarakat dunia, khususnya muslim.

Peran NU dan MD di kancah internasional juga bisa dilihat melalui situs resmi kemenlu ketika Yenni Wahid, Azyumardi Azra dan juga Romo Magnis (sebagai perwakilan bangsa Indonesia yang beragama Kristen) menuai apresiasi dari warga Norwegia. Seminar itu mengambil tema "Challenging Islamic Exstrimism in Indonesia" hasil kerja sama KBRI Oslo dan Peace Research Institute Oslo (PRIO), 2019. Dalam paparannya, Azra mengungkapkan bahwa organisasi muslim, termasuk NU dan Muhammadiyah sangat berpengaruh dalam memainkan proses mediasi dan menjembatani seluruh lapisan masyarakat dengan

\footnotetext{
72 Rumadi, Hasil-hasil Muktamar, hal. 389-392.

${ }^{73}$ Abdallah Schleifer (ed), The Muslim 500: The World's 500 Most Influental Muslim 2020 (Jordan: Jordan National Library, 2019). Dalam menanggapi tokoh-tokoh berpengaruh ini, penulis juga telah mengemukakan pandangannya dalam https://islami.co/ketika-ulama-indonesia-menghiasi-daftar-500muslim-berpengaruh-di-dunia/. diakses pada 31-10-2019.
} 
pemerintah, dan menjadi aktor penting dalam menciptakan dan menjaga perdamaian. Yenny juga menyampaikan bahwa peran dan pengaruh NU dan Muhammadiyah dalam menghadapi extremisme dan radikalisme seharusnya dapat juga merambah negara lain di luar Indonesia.

Menghadapi pertanyaan dari peserta yang mengkhawatirkan keadaan Indonesia yang dinilai semakin tidak kondusif dengan banyaknya kelompok Islam Radikal, Yenny, Magniz-Suseno, dan Azra sependapat bahwa kekhawatiran tersebut wajar, namun selama Indonesia masih memiliki organisasi Islam yang toleran dan damai seperti NU dan Muhammadiyah, maka Indonesia akan selalu utuh dan damai. ${ }^{74}$

Gerakan Islam transnasional mulai datang ke Indonesia ketika beberapa tokoh Indonesia seperti Haji Miskin dkk-yang sudah terkena paham Wahabi di Saudi-pulang ke kampung halamannya. Ketika Haji Miskin dkk ini melihat keislaman di Sumatera Barat yang berbeda dengan ajaran yang mereka dapat, langkah cepat mereka lakukan. Mereka menganggap bahwa praktek Islam di Sumbar waktu itu tidak murni dan sudah terkontaminasi dengan tradisi setempat. Dari sinilah akhirnya Perang Padri berkobar.

Pengaruh Islam transnasional selepas peristiwa Padri tidak terulang lagi selama beberapa dekade. Hal ini dikarenakan bangsa Indonesia lebih disibukkan dengan perlawanan terhadap penjajahan Belanda, bahkan Jepang walau sesaat. Setelah Indonesia merdeka, gerakan Islam transnasional masih belum terlihat. Sampai akhirnya setelah kepemimpinan Soekarno dan Soeharto usai, tepatnya di era reformasi. Berbagai gerakan atau ormas Islam mulai muncul ke permukaan. Tak ayal, kelompok seperti HTI, Ikhwanul Muslimin (melalui gerakan tarbiyahnya), dan Salafi mulai menarik minat sebagian

${ }^{74}$ https://kemlu.go.id/oslo/id/news/1134/upaya-nu-dan-muhammadiyah-berantasradikalisme-dan-extremisme-tuai-apresiasi-dari-publik-norwegia diakses pada 31-10-2019. 
masyarakat Indonesia. Bahkan, pada tahun-tahun berikutnya PKS (mewakili perjuangan IM) mampu menyusup ke dalam tubuh MD. Infiltrasi Islam transnasional juga pernah menimpa NU. Karena itulah, kedua ormas Islam pejuang moderasi ini akhirnya mengevaluasi dirinya. Puncak dari "perlawanan" NU dan MD ada dalam muktamar keduanya di tahun 2015. Dari tahun 2015 sampai sekarang, keduanya tercatat sebagai penjaga gawang warna Islam moderat Indonesia. Bahkan, warna Islam moderat ini telah dan terus dijual ke "pasar" dunia.

\section{PENUTUP}

Gerakan Islam transnasional mulai datang ke Indonesia ketika beberapa tokoh Indonesia seperti Haji Miskin dkk-yang sudah terkena paham Wahabi di Saudi_pulang ke kampung halamannya. Ketika Haji Miskin dkk ini melihat keislaman di Sumatera Barat yang berbeda dengan ajaran yang mereka dapat, langkah cepat mereka lakukan. Mereka menganggap bahwa praktek Islam di Sumbar waktu itu tidak murni dan sudah terkontaminasi dengan tradisi setempat. Dari sinilah akhirnya Perang Padri berkobar.

Pengaruh Islam transnasional selepas peristiwa Padri tidak terulang lagi selama beberapa dekade. Hal ini dikarenakan bangsa Indonesia lebih disibukkan dengan perlawanan terhadap penjajahan Belanda, bahkan Jepang walau sesaat. Setelah Indonesia merdeka, gerakan Islam transnasional masih belum terlihat. Sampai akhirnya setelah kepemimpinan Soekarno dan Soeharto usai, tepatnya di era reformasi. Berbagai gerakan atau ormas Islam mulai muncul ke permukaan. Tak ayal, kelompok seperti HTI, Ikhwanul Muslimin (melalui gerakan tarbiyahnya), dan Salafi mulai menarik minat sebagian 
masyarakat Indonesia. Bahkan, pada tahun-tahun berikutnya PKS (mewakili perjuangan IM) mampu menyusup ke dalam tubuh MD. Infiltrasi Islam transnasional juga pernah menimpa NU. Karena itulah, kedua ormas Islam pejuang moderasi ini akhirnya mengevaluasi dirinya. Puncak dari "perlawanan" NU dan MD ada dalam muktamar keduanya di tahun 2015. Dari tahun 2015 sampai sekarang, keduanya tercatat sebagai penjaga gawang warna Islam moderat Indonesia. Bahkan, warna Islam moderat ini telah dan terus dijual ke "pasar" dunia.

\section{DAFTAR PUSTAKA}

\section{Buku dan Jurnal:}

Abdullah, Taufik (ed.), Sejarah dan Masyarakat (Jakarta; Pustaka Firdaus, 1987)

Abu Za'rur, Seputar Gerakan Islam (Bogor: al-Azhar Press, 2016)

Alles, Delphine, Transnational Islamic Actors an Indonesia's Foreign Policy, (New York: Routledge, 2016)

Aritonang, Jan S, Sejarah Perjumpaan Kristen dan Islam di Indonesia (Jakarta: BPK Gunung Mulia, 2004)

B. Tylor, Edward, Primitive Culture: Research into the Development of Mythology, Philosophy, Religion, Language, Art and Custom (New York: Brentano's Publishers, t.t.)

Burhani, Ahmad Najib, Internasionalisasi Mubammadiyab: Agenda Promodi Pemikiran dan Gerakan, dalam Islam Berkemajuan untuk Peradaban Dunia (Bandung: Mizan Pustaka, 2015)

Bush, Robin, Nahdlatul Ulama' and the Struggle for Power within Islam and Politics in Indonesia (Pasir Panjang: ISEAS, 2009)

Calvin Ricklefs, Merle, A History of Modern Indonesia since c 1200, $3^{\text {rd }}$ edition (Great Britain: Palgrave, 2001)

Citra Hati, Putri, 'Dakwah pada Masyarakat Minangkabau: Studi Kasus Pada Kaum Padri', Islamic Communication Journal, 3.1 (2018)

Drajat, Zakiyah (peny) Perbandingan Agama I, (Jakarta: Bumi Aksara, 1996) 
Effendi, Bahtiar, Islam dan Negara: Transformasi Gagasan dan Praktik Politik Islam di Indonesia.terj, (Demokrasi Project, 2011)

Fakhruddin, M. Anas, 'Kontra Ideologi Terorisme menurut Nahdlatul Ulama' dan Muhammadiyah di Lamongan' Jurnal Review Politik, 7.1 (2017)

Fealy, Greg, Ijtihad Politik Ulama': Sejarah NU 1952-1967 (Yogyakarta: Lkis, 2003)

Hilmy, Masdar, 'Akar-akar Transnasionalisme Islam HTI', Islamica, 6.1 (2011)

Husni, Zainul, Mu'ien, 'NU di Tengah Pusaran Ideologi-ideologi Transnasional', 2.1 (2018)

Inayati, Fahrida dan Rifqi Setiawan, Adib, "Islam Nusantara: Glance History, Characteristics, and Criticism," Alobatnis Research Society $(\Lambda \mathrm{RS})$, March 24, 2018.

Indradjaja, Agustijanto, 'Awal Pengaruh Hindu Budha di Nusantara', Kalpataru, Majalah Arkeologi, 23.1 (2014)

Jamhari dan Jahroni, Jajang (Peny), Gerakan Salafi Radikal di Indonesia (Jakarta: Raja Grafindo, 2004)

Jazimah Puji Astuti, Hanum, 'Islam Nusantara: Sebuah Argumentasi Beragama dalam Bingkai Kultural', INJECT: Interdisciplinary Journal of Communication, 2.1 (2017)

Khoirul Fata, Ahmad dan Ikhwan, Moh Nor, 'Pertarungan Kuasa dalam Wacana Islam Nusantara', Islamica: Jurnal Studi Keislaman, 11.2 (2017)

Kurniawan Wibowo, Eko, 'Membincang Gerakan Islam Transnasional', Diegesis: Jumal Teologi, 3.3 (2018)

Latief, Hilman, Post Puritanisme: Pemikiran dan Arah Baru Gerakan Islam Modernis di Indonesia 1995-2015 (Yogyakarta: LP3M UMY, 2017)

M. Abou El-Fadl, Khaled, Selamatkan Islam dari Muslim Puritan, terj. Helmi Mustofa,

Mandaville, Peter, Global Political Islam (London: Routledge, 2007)

Mansur Suryanegara, Ahmad, Api Sejarah 1 (Bandung: Surya Dinasti, 2015)

Muhammad al-Thabari, Abu Ja'far, Jami' al-Bayan fi Tafsir al-Qur'an, juz 2 (Dar al-Hijr, tt) 
Mustafa Harun, Ahmad, Menegubkan Islam Nusantara: Biografi Pemikiran dan Kiprah Kebangsaan Prof. KH. Said Aqil Siraj (Surabaya: Khalista, 2015)

NA, Thomas, dkk, 'Pancasila Ideology vs Transnational Ideology Movement' Proceeding, The 5th International Conference on Education \& Social Sciences (ICESS).

Pimpinan Pusat Muhammadiyah, Tanfidz Keputusan Muktamar Mubammadiyah ke-47 (Yogyakarta: Gramasurya, 2015)

Qohar, Abdul dan Muhammad Hakiki, Kiki, "Eksistensi Gerakan Transnasional HTI Sebelum dan Setelah Pembubaran," Kalam, $11.2(2017)$

Qomar, Mujamil, Fajar Baru Islam Indonesia, (Bandung: Mizan, 2012)

Rahmad, Imaduddin, Arus Baru Islam Radikal (Jakarta: Erlangga, 2005)

Ridha, Muhammad Rasyid, Tafsir al-Manar, juz 2 (Mesir: Hai'ah Misriyyah, 1990)

Rumadi, dkk (ed), Hasil-hasil Muktamar ke-33 Nabdlatul Ulama', cet. 2 (Jakarta: Lembaga Ta'lif wan Nasyr PBNU, 2016)

Schleifer, Abdallah (ed), The Muslim 500: The World's 500 Most Influental Muslim 2020 (Jordan: Jordan National Library, 2019)

Solahudin, NII Sampai JI: Salafy JIhadisme di Indonesia (Depok: Komunitas Bambu, 2011)

Sugono, Dendy (Pemimpin red), Kamus Besar Babasa Indonesia (Jakarta: Pusat Bahasa Departemen Pendidikan Nasional, 2008).

Sunyoto, Agus, Atlas Walisongo, (Depok: Pustaka Ilman, 2016)

The Oxford Paper Back Dictionary (London: Oxford University Press, 1994)

Tim Aswaja NU Jawa Timur, Khazanah Aswaja: Memahami, Mengamalkan dan Mendakwabkan Ablussunnah Wal Jama'ah (Surabaya: Aswaja NU Center, 2016)

Van Bruinessen, Martin, 'Genealogies of Islamic Radicalism in PostSoeharto Indonesia', South East Asia Research, 10.2, (2002)

Wahid, Abdurrahman (ed), Ilusi Negara Islam: Ekspansi Gerakan Transnasional di Indonesia (Jakarta: The Wahid Institute, 2009)

Wahid, Din, 'Kembalinya Konservatisme Islam Indonesia', Studia Islamika, 21.2 (2014) 
Yilmaz, Ihzan, 'Transnational Islam', European Journal of Economic and Political Studies, (2010)

\section{Sumber Internet dan Video:}

Azra, Azyumardi, Islam With Smiling Face (Video Democracy Project, Yayasan Abad Demokrasi, 2013)

https://www.nu.or.id/post/read/66603/kang-said-agar-tak-salahpaham-islam-nusantara-bertabayunlah-ke-pbnu diakses pada 3010-2019.

https://www.bbc.com/indonesia/berita indonesia/2015/06/150614 in donesia islam nusantara diakses pada 31-10-2019.

https://www.republika.co.id/berita/kolom/resonansi/15/06/17/nq3f9 n-islam-nusantara-1 diakses 30-10-2019.

http://www.muhammadiyah.or.id/id/news-15250-detail-din-kembaliterima-gelar-kehormatan-dari-pemerintah-jepang.html diakses pada 31-10-2019.

https://islami.co/ketika-ulama-indonesia-menghiasi-daftar-500-muslimberpengaruh-di-dunia/. diakses pada 31-10-2019.

https://kemlu.go.id/oslo/id/news/1134/upaya-nu-danmuhammadivah-berantas-radikalisme-dan-extremisme-tuaiapresiasi-dari-publik-norwegia diakses pada 31-10-2019.

https://news.detik.com/berita/2980904/presiden-jokowi-apresiasitema-muktamar-ke-33-nu-islam-nusantara diakses pada 30-102019. 